\title{
Postcolonial theory as a hermeneutical tool for Biblical reading
}

\author{
Lazare S Rukundwa ${ }^{1}$ \\ Research Associate: Faculty of Theology \\ University of Pretoria
}

\begin{abstract}
In this article, postcolonial theory is presented as a tool for Biblical interpretation, in an attempt to find colonial intentions (be they political, cultural or economic) that informed and influenced the writer's context. Although criticism has been levelled at the church and other religious institutions for having, consciously or unconsciously, facilitated colonial conquests and imperial establishment all over the world, postcolonial theory calls them to a constructive reading that enables readers to see the concerns of the universal mission of justice. Postcolonial theory, as a tool for Biblical interpretation, deals with the Bible as a "cultural product" in time and space. However, as part of socio-scientific method, postcolonial theory encounters some crucial translation problems such as ethnocentrism and anachronism. Nevertheless, whatever hermeneutical tool the reader uses, it must yield two important things from Scripture reading: discovering life and discovering faith.
\end{abstract}

\section{INTRODUCTION}

Over the past decades, theologians and exegetes have cautiously started to explore avenues of contextual interpretation of the Bible. These avenues included post-structural theory and postmodern theory. In pursuit of biblical understanding in contexts locked into socio-political and economic upheavals, postcolonial theory is taking the lead. In academic and research institutions, this field of study is increasingly attracting greater interest from feminist and tricontinental readings. The questions dealt within this article range from

\footnotetext{
${ }^{1}$ Dr Lazare S Rukundwa is the Executive Secretary of Eben-Ezer Ministry International in the Democratic Republic of Congo. The article is the second of two focusing on the relevance of postcolonial theory for Biblical hermeneutics. These articles are based on Dr Rukundwa's thesis for his PhD degree in New Testament Studies at the Faculty of Theology, University of Pretoria, entitled "Justice and righteousness in the Matthean theology and its relevance to the Banyamulenge community: A postcolonial reading", completed under the supervision of $\mathrm{Dr}$ Andries G van Aarde, honorary professor at the Faculty of Theology, University of Pretoria.
} 


\section{Postcolonial theory as a hermeneutical tool for Biblical reading}

social-scientific criticism in general to the use of postcolonial theory in biblical interpretation in particular.

The article argues that biblical interpretation emerges from a social environment, which is built (within) and influenced by both internal and external factors. Postcolonial biblical criticism is concerned with the sociopolitical context in which the voice of the other is being silenced. It deals with the contexts whereby socio-political powers and identities are constructed. Postcolonial theory takes into consideration the situation of the coloniser as well as the colonised, in order to reconstruct a negotiating space for equity. Under postcolonial theory, theologians argue that biblical texts have been marked as powerful rhetorical instruments of imperialism. But at the same time, biblical texts have also been proclaimed in colonial settings and therefore contain a voice of justice that energises faith to challenge injustice committed against the weak.

\section{SOCIAL-SCIENTIFIC CRITICISM}

The obvious question to start with is: Does postcolonial theory fit the models of biblical research? How can these models be drawn? Malina (1983:14; cf Craffert 1992:224-226; Elliott 1993:41) defines a model as an "abstracted simplified representation of some real world object, event, or interaction constructed for the purpose of understanding, control, or prediction". Models can be viewed as tools in human processes, which facilitate an understanding of a given context under investigation (cf Elliott 1993:42). In addition, Carney (1975:7-9; cf Esler 1995:4-8; Vledder 1997:25; Horrell 1999:19-20; Van Aarde 2002:419-439) makes the point that a model works as a "tool or speculative instrument" used to transform theories into research actions. Malina and Rohrbaugh (1992:4-5) add that "people think with models in order to understand, control, and/or predict" and that they are "cognitive devices" to help "to unearth dimensions of a setting not at once apparent" and to develop "the ramification of such dimensions".

According to Elliott (1993:44), models "are used explicitly to articulate ... theories and test their validity". Carney (1975:8) states that theory is defined as "a basic proposition through which a variety of observations or alternatively statements become explicable. A model, by way of contrast, acts as a link between theories and observation". In this case, a theory serves as a foundation on which models are built in order to produce a working methodology in a particular study. 
Elliott (1993:34-59) emphasises two types of models of interest to this study, namely sectarian and conceptual models. Sectarian models (cf Esler 1994: 13-17) are employed in features such as communal identity, cohesion and ideological commitment. They are useful in explaining tension based on a binary concept or on cultural or identity differences such as insiders/outsiders, Jew/Gentile, coloniser/colonised, male/female, rich/poor, master/slave, et cetera. Conceptual models (Elliott 1993:44; cf Van Staden 1991:158) serve as "vehicles for discovery, trying out new points of view, asking new questions" but also provide explanations and the information required "to articulate a working model."

Based on social and anthropological studies, Elliott (1993:38; cf Van Staden 1991:152-155) mentions two concepts for conveying information: emic and etic. Emic identifies the "information provided by 'natives'", as perceived and narrated or explained from natives' experience. It "describes what and how the native thought". By contrast, etic deals with "the perspective of the external investigator" as determined by the knowledge available to him/her. It employs cross-cultural comparison "by taking into account a full range of factors not mentioned or considered in native reports ... They seek to explain why the native thought and behaved so and not otherwise".

Therefore, as Elliott (1993:37-38) notes, a method of analysis can include both emic and etic concepts as the "means for distinguishing and clarifying the differences between the social location of the interpreter and the social location of the authors and the objects to be interpreted'. This social location encompasses all aspects of social life, such as social classes, gender, ethnicity, roles and status, nationality, occupation, education, group membership, political and religious affiliation, language and cultural traditions, and location in time and space. It is from this angle that postcolonial theory poses the question of social-political and economic equity for silenced voices.

\section{POSTCOLONIALISM AND BIBLICAL CRITICISM}

Over the past decades, theologians and exegetes have cautiously started to explore a political hermeneutical avenue by using post-structural theory (Moore 1994), postmodern theory (Adam 1995, 2001; Van Aarde 2004) and feminist reading (Wire 1991:87-121; Wainwright 1998; Levine 1996:379-397; Kaene 1998:121-135; Levine \& Blickenstaff 2001; Jackson 2002, Schroer \& Bietenhard 2003). As postcolonial theory is used, essays ranging from theoretical to practical case studies from biblical texts, as well as contemporary cases are on the increase. Sugirtharajah's edited work on 


\section{Postcolonial theory as a hermeneutical tool for Biblical reading}

Voices from the margin ${ }^{2}$ is recognised as a good contribution for postcolonial theory in biblical criticism.

The research studies and essays that appear in the edited work of Segovia and Tolbert (1995) ${ }^{3}$ and in two volumes in Semeia 75/76 (1996), 78 (1997) as well as in issues of the Journal for the Study of the New Testament (JSNT) 73 \& 75, (1999), Segovia (2000), Sugirtharajah (2001), Moore (2001), are some examples of the growing interest in this field. From a Southern African perspective, Dube (1996:111-129; 1997:11-25; 2000), Mosala (1996:43-57), Punt (2001:129-145; 2003:59-85) and Van Aarde (2004) are among those who have shown an interest in and who have contributed to the study of this field.

Segovia's (1999:103-114; cf 1995a:1-17) initial difficulty was in identifying with the "postcolonial studies" in biblical criticism. Punt (2001:130131) sees postcolonial biblical criticism as having "a different focus and purpose, rather than a different hermeneutical method". In other words, postcolonial biblical criticism is a "form of ideology criticism, which considers the socio-political context" and goes even further to address "the silencing of the voice of the Other through the colonial strategy" (Punt 2003:63) in a postcolonial setting. It focuses on national issues such as race, gender, class, tribe, citizenship and the construction of political powers within sociological and geographical settings.

Sugirtharajah (1999:3-5; 2001:250-259; cf Punt 2003: 65-66; cf Segovia 1995a:1-17) as one of the main campaigners of this theory in biblical scholarship, states that postcolonial criticism as a biblical hermeneutics, can help (i) to "revalue the colonial ideology, stigmatisation and negative portrayals embedded in the content, the plot and characterisation". It entails looking for the colonial intentions (be they political, cultural or economic) that informed and influenced the writer's context. (ii) It helps in "reconstructive reading" which enables the reader to see the concerns of the liberation struggles of the past and the present. Postcolonial critique, therefore, is concerned and interacts with circumstances such as hybridity (mestiza,

\footnotetext{
${ }^{2}$ Sugirtharajah, R S (ed), Voices from the margin: interpreting the Bible in the Third World, London: SPCK, 1995.

${ }^{3}$ Segovia, F F \& Tolbert, A M, Reading from this place: Social location and biblical interpretation in global perspective, vol 2, Minneapolis, MN: Fortress Press, 1995. This work is a compilation of many views and practices of postcolonial readings, although the term as such is not implicitly used. Contributors prefer to use cultural studies and biblical criticism (cf also Segovia 1999:103-114).
} 
akamecerane), ${ }^{4}$ new identities, fragmentation and deterritorisation. (iii) Postcolonial criticism interrogates colonial interpretation "to draw attention to the inescapable effects of colonisation and colonial ideals." It investigates interpretations that "contested colonial interests". Such a view helps to establish a reconstructed identity from the colonial context.

\section{POSTCOLONIAL THEORY AND THE BIBLE}

Talking from an African perspective, Dube (2000:15-21) draws her critique against the misuse of the Bible by the colonisers as they seized African land. She is convinced that "by implicating the Bible in the taking of the African black lands, biblical texts are marked as powerful rhetorical instruments of imperialism". Subjugation and alienation are seen as the result of weak evangelism in Africa, which was not a cultural exchange, but rather a cultural domination and assimilation (see Dube 1997:20). Dube (1997:15; cf Sugirtharajah 1998:19) is disturbed by the imperial role that Christian biblical religion played "in the ancient and current times and over different people and different places". She sees the Bible as "a colonizing text: it has repeatedly authorized the subjugation of foreign nations and lands". However, biblical texts also emerge from colonial and imperialist contexts and therefore contain a call for liberation (cf Dube 1997:15; Punt 2003:61-64). Pui-lan (1996:213) argues that since biblical texts are products of colonial experiences, a postcolonial reading must "examine the cultural and historical processes that call them into being."

The work of liberation theology is a noble achievement, as it stages campaigns against poverty and socio-political injustices in Latin America and in Africa. Postcolonial theory builds on these very campaigns to enlarge the scope of justice and freedom, whereby the marginal persons recover their dignity. A postcolonial reading of the Bible is a war against sin: colonialism, neocolonialism, dictatorship, corruption and social injustices in every aspect of society, regardless of their agent. In this case, postcolonialism "is not a discourse of historical accusations, but a committed search and struggle for decolonization and liberation of the oppressed" (Dube 1997:14).

However, what is challenging is that the Bible, as a text, was produced and circulated under imperial rule, to the extent that it was at the service of colonial expansion, as Punt and many others argue (Punt 2003:71; cf Pui-lan 1996:212; Tamez 1996:203-205). For Pui-lan (1996:212-213), the introduction of postcolonial hermeneutics provides new avenues of interrogating the Bible as "a cultural product, the formation of canon, and the politics of biblical

\footnotetext{
${ }^{4}$ The word for hybrid in Kinyamulenge dialect.
} 


\section{Postcolonial theory as a hermeneutical tool for Biblical reading}

interpretation". Two issues arise here: firstly the Bible as a cultural product in time and space and secondly, the authority of biblical interpretation.

The first issue has to do with the question of biblical interpretation. Puilan challenges those who dominated biblical hermeneutics, as if the Bible were "a frozen artefact", whose meaning can only be activated by "the experts in the metropolitan centres ... under the rubric of 'objectivity' and 'scientific inquiry'”. With this traditional and colonial thinking (see Tamez 1996:204), tricontinental biblical scholars cannot, from their own cultural and contextual understanding, have direct access to the biblical text.

This triangular hermeneutics (the Bible provides the text - the Western theologian produces the hermeneutics - the rest of the world reads) - needs to be reviewed in the postcolonial process. The idea is not to destroy the hermeneutical tools produced by Western theologians, but to recognise the hermeneutical principles that respond to the needs of the tricontinental context. Ukpong (2001:147-167) strongly emphasises the need for "decolonizing our readings". Arguing from an African perspective, Ukpong (2001:158) points out that if exegesis is to be truly contextual and African, "an ideological break with the western centrist ideology" is necessary. African perspectives and contexts must stimulate exegetes to formulate questions that are relevant to their own situations. "We must engage in serious and innovative research that will open up new vistas in biblical scholarship."

In Pobee's edited work (1992), the various contributors in their search for an "Afro-Christology" grapple with the meaning of Christianity. Pobee (1992:13-15) is convinced that Africa, after having been invaded by foreign cultural influence and colonisation, is now as the "homo africanus" in a state of flux, if not confusion, and that articulation of "African anthropology as of now is a must". The development of tricontinental biblical reading must be grounded in tricontinental worldviews and contexts. The delivery of biblical interpretation developed in a foreign context cannot effectively respond to the socioeconomic, political and religious challenges of another social setting (see Kalilombe 1995:421-422). Steve Biko's "Black Consciousness" (Hopkins $1991: 194-200)$, developed within biblical perspectives, is meangful. He was conviced that the Christian gospel will find God of the Blacks through Jesus Christ siding with the racially oppressed. Tricontinental biblical Christology must find its meaning in the Word - Life that became flesh and dwelt among the people (Jn 1:12).

These foreign hermeneutics are incapable of explaining the harsh realities of inequality, oppression and exploitation that are often experienced in tricontinental countries. As long as the Christology of Jesus remains foreign, Jesus will remain unknown. As Mbiti (1992:28) puts it: "His many 
faces are blurred till they find a focus on the Jesus of history and geography," not from a theoretical foreign interpretation, but in a local context. The Word must be understood, digested until it becomes "flesh and blood" as Senghor (1964:83) refers to it, as does Segovia (1995a:3-7) too.

Experiences of pain, the long walk to freedom and rich cultural diversity in songs, dances, dreams, and religious practices (compatible with the Word of God), must be engaged in rebuilding a society based on justice and righteousness. This is the work of the deconstructive process through which a postcolonial reading lets the voiceless speak and lets the oppressed participate fully in the struggle for their deliverance (see Kalilombe 1995:421435). Biblical hermeneutics must allow the Scriptures to breathe life and respond to the context that motives its reading. This is how the Bible, the Word of God, which liberates and revolutionises, is constantly rediscovered. The meaning and the relevance of that Word - Life must be found in tricontinental anthropology, in the community of the poor, the marginalised, among the voiceless and the hybrids whose identity is constantly being contested. At the same time, the purpose of this very Life is to change the lives of the colonisers by making them recognise the sameness in the other.

The second issue in Pui-lan's critique (1996:213) is that the Bible is a cultural product in time and space: both the truth and the authority of the Bible are questionable. Kunukawa (1996:123-125; see Sugirtharajah 1995:4-5; 2001:257-258) questions "religionism and absolutism" as opposed to "relativisation". Her argument is that the relativisation of the biblical texts turns them into "one of the historical treasures in the world" and these texts are acknowledged as a "human product with distinctive perspectives in one's own distinct contexts".

Banana (1995:69-82) calls for a rewriting of a new Bible in order to liberate it from "culture-specific world views"; from constantly being used as "an oppressive instrument"; and from being "a property of an ethnic syndicate". This "multiscripturality" as Punt (2003:72) calls it, not only requires the discovery and creation of new texts, but also coming to terms with other "religious texts". Tamez (1996:205) is convinced that the "hermeneutical leap" in biblical reading demands an acknowledgement that colonial elements were already present during the production of the text and transcended the canon. Therefore, postcolonial or "grassroots" hermeneutics must assume the task of "re-appropriating the biblical texts and re-reading them from a liberating perspective".

Sugirtharajah (2001:257-258) thinks that in an age when traditional sources such as sacred text, the Bible among them, are questioned, these may not be the only avenues for answers. For this reason, he sees the aim of 


\section{Postcolonial theory as a hermeneutical tool for Biblical reading}

postcolonial reading not as "to invest text with properties which no longer have relevance to our context"; not to rediscover the Bible as an alternative for a better world; nor to approach it for its "intrinsic authoritativeness"; but because of the "thematic presuppositions of postcolonialism" that are influenced by the cultural and psychological effects of hybridity and alienation caused by colonialism. The "truth of the text" is questionable here, and Punt (2003) is right to be concerned.

[I]f in the framing of the postcolonial hermeneutics it is in the final instance not concerned with the "truth of text" but rather with the central issue of the text's promotion of colonial ideology ... its usefulness on the African continent where the Bible is still highly valued for many reasons, becomes a concern. If the Bible is studied only for identifying "those intrinsic textual features which embody colonial codes", and when the value of studying these texts for their own sake or for theological and spiritual inspiration are secondary at best, it remains a question whether postcolonial hermeneutics are not short-circuiting itself, in Africa, but also elsewhere.

(Punt 2003:72)

Reading the Bible for the sake of hermeneutical rehearsal cheapens the raison d'être of the postcolonial endeavour. Okure (1995:52-66; cf Mesters 1995:407-420) highlights some of the difficulties associated with cultural criticism (postcolonial approach) as it deals with biblical texts. One of the problems centres on "the nature of the text itself as the life of a given people and as the inspired word of God".

Another problem is "the right of an author to his or her meaning". Although the text is influenced by its context, in Christian communities the Bible remains the inspired Word of God. Okure's (1995:55) question: "How does one safeguard the authenticity of the meaning of the text and guard against subjectivism?" is fundamental. Mesters (1995:415-416) has reason to argue that the tools one adopts in reading the Bible are much more than a set of techniques. They must be able to express, actualise and transmit "a particular vision of the Bible and revelation." Segovia (1995b:327-330) outlines some of the reasons why the Bible must remain as an "effective weapon" and a "faithful ally" in the struggle for liberation, in this case using postcolonial theory. Any method used to interpret biblical text must have, as its point of departure, real life and a community's faith.

Whatever hermeneutical tool the reader uses, the important thing in the Scriptures is to discover life and faith. Taking the example of Latin America in the light of liberation theology, Sugirtharajah (2001:218) makes an important 
point. Ordinary people look for two important meanings in a text, namely "historical-explicit and implicit-prophetic" meaning. If postcolonial theory fails to channel its focus towards meeting those spiritual and physical needs, it can easily end up re-colonising the subject that it wants to decolonise. Tamez's (1996:205) proposition is both interesting and challenging. Appreciation for other liberating forms of aura/oral religious traditions and even from other religious texts, songs and political discourses, not resulting in biblical texts, need not be pushed aside or replaced. It is rather a case of interpreters and readers finding a common ground for dialogue in "a world where many worlds fit" $^{5}$ as long as it imparts life and generates faith and hope to challenge oppression, domination, exploitation and injustice committed against the poor in the community.

\section{LIMITATIONS OF POSTCOLONIAL THEORY}

Postcolonial theory is a paradoxical exercise, especially when it deals with locations and specifics, in a world of generalisation and globalisation, by seeking recognition of an identity within a world of cultural diversities. Ivison (1997:154) laments that it is "extremely difficult to establish a general sense of postcolonialism", since it means different things to different people with different histories in different contexts. This is because of the continuity within the discontinuity of colonialism and imperialism in the postcolonial era.

As is the case with any social-scientific method, postcolonial theory has the same translation problems as many social-scientific theorists warn (Riley 1963:704-716; Judge 1980:201-217; cf Van Staden 1991:166-117; Elliott 1993: 38; Craffert 1992:217-239; Esler 1994:4; Robbins 1994:277-279; Vledder 1997:22-23; Van Aarde 2004:14-15). According to Riley (1963:704707; cf Van Staden 1994:166-167), fallacies arise in research, either because "methods fail to fit model" 6 or "methods fail to fit facts". ${ }^{7}$ Consequently,

\footnotetext{
${ }^{5}$ Tamez quotes the Mexican revolutionary movement's creed of the Zapatista with a perspective of a "house in which there is room for everybody".

${ }^{6}$ The explanation given by Riley (1963:704) and Van Staden (1994:166) shows that this type of fallacy occurs when a researcher chooses a research case from a social system that does not fit his/her conceptual model, for example if the model refers to individuals in roles, whereas the researcher bases his/her analysis on the group. This is called aggregative fallacy, whereas atomistic fallacy occurs when the researcher's model refers to the group, but the researcher's analysis is based on individuals.

${ }^{7}$ From the same explanation as above, two other fallacies occur, namely psychological and sociological. In this instance, the method may fit the model, but fails to discover the relevant facts. Consequently, the group data alone may not adequately prevent a sociolinguistic fallacy even when the focus is on the group; nor can individual data alone prevent a psychologistic fallacy, even when the focus is on the individual.
} 


\section{Postcolonial theory as a hermeneutical tool for Biblical reading}

postcolonial theory becomes vulnerable to ethnocentrism and may become an anachronism.

Van Aarde (2004:14-15; cf 2002:419-422) is cautious of ethnocentrism. Since postcolonial biblical reading is concerned with the cross-cultural dynamics of the culture of people in biblical times and the cultures of the tricontinental world in a postcolonial era, "the hermeneutical 'fallacy of ethnocentrism"' is a real danger. Cultures are not necessarily the same; even if there are some similarities, they remain different. This cultural difference and distinction "function on a synchronic as well as a diachronic level". The first problem that postcolonial theory faces lies in its formation. Even cultures in a "contemporaneous time-span", for example Asian and African cultures, are not similarly constituted.

Furthermore, postcolonial theory takes its shape from modern industrialisation and the globalisation influence occurring after colonisation. Consciously or unconsciously, this influence has left its mark on the native cultures from which postcolonialism emerge. Cultural distance is even more complicated in the case of ancient and biblical societies, separated by so many centuries. As Rohrbaugh (1996:2-6) explains, the use of a cultural reading of the New Testament, leading to a cross-cultural understanding, can cause culture shock, because readers are cut off from the things that are familiar to them.

Using postcolonial theory to investigate both the biblical text and context of the ancient period can result in an "anachronistic and historical" exercise (see Van Zanthen Gallagher 1996:230; cf Condran 1997:54). According to Moore (2001:185), postcolonial studies pose a formidable "translation" problem for students of ancient literature (cf Gallagher 1996:230-233; Van Aarde 2004:14). Harmony between time and space in the construction of cultures is a constant challenge. In the words of the Apostle Paul, it would be: "Not that I have already obtained all this ... but I press on ..." (Phlp 3:12). Nevertheless, as a biblical hermeneutical tool, postcolonial theory paves the way for a hybrid reconciliatory process which builds the Kingdom of God that in turn brings life and faith to every culture.

\section{Works consulted}

Adam, M K A 1995. What is postmodern biblical criticism? Minneapolis, MN: Fortress.

Adam, M K A (ed) 2001. Handbook of postmodern biblical interpretation. St Louis, MO: Chalice.

Banana, S C 1995. The case of a New Bible, in Sugirtharajah 1995:69-82. 
Carney, T F 1975. The shape of the past: Models and antiquity. Lawrence, MA: Coronado.

Condren, C 1997. Political theory and the problem of anachronism, in Vincent, A (ed), Political theory: Tradition and diversity, 45-66. Cambridge: Cambridge University Press.

Craffert, F P 1992. More on models and muddles in social-scientific interpretation of the New Testament: the sociological fallacy reconsidered. Neotestamentica 26(1), 217-239.

Dube, W M 1996. Reading of Semoya: Batwana women's interpretations of Matthew 15:21-28. Semeia 73, 111-129.

Dube, W M 1997. Toward a postcolonial feminists' interpretation of the Bible. Semeia $78,11-25$.

Dube, W M 2000. Postcolonial feminist interpretation of the Bible. St Louis, MO: Chalice.

Elliott, J H 1993. Social-scientific criticism of the New Testament: An introduction. London: SPCK.

Esler, P F 1994. The first Christians in their social worlds: Social-scientific approaches to the New Testament interpretation. London: Routledge.

Esler, P F (ed) 1995. Modelling early Christianity: Socio-scientific studies in the New Testament in its context. London: Routledge.

Esler, P F 1995. Models, context and kerygma in New Testament interpretation, in Esler 1995:1-19.

Hopkins, D 1991. Steve Biko, black consciousness and black theology, in Pityana, B N, Ramphele, M, Mpumlwana M \& Wilson, L, Bounds of possibility: The legacy of Steve Biko and black consciousness, 194200. Cape Town: David Philip.

Horrell, G D 1999. Social-scientific interpretation of the New Testament. Retrospect and prospect, in Horrell, G D (ed), Social-scientific approaches to New Testament interpretation, 3-27. Edinburgh: T\&T Clark.

Ivison, D 1997. Postcolonialism and political theory, in Vincent, A (ed), Political theory: Tradition and diversity. 154-171. Cambridge: Cambridge University Press.

Jackson, S G 2002. "Have mercy on me": The story of the Canaanite woman in Matthew 15:21-28. Sheffield: Sheffield Academic Press.

Judge, E A1980. The social identity of the first Christian: A question of method in religious history. JRH 11, 201-217.

Kaene, M-H 1998. Feminist and womanist theology, in Maimela \& König 1998:121135.

Kalilombe, A P 1995. A Malawian example: the Bible and non-literate communities, in Sugirtharajah, S R (ed), Voice from the margin. Interpreting the Bible in the Third World, 420-435. London: SPCK.

Levine, A-J 1996. Discharging responsibility: Matthean Jesus, biblical law, and hemorrhaging woman, in Bauer \& Powell 1996:379-397.

Levine, A-J \& Blickenstaff, M (eds) 2001. A feminist companion to Matthew. Sheffield: Sheffield Academic Press.

Loomba, A 1998. Colonialism/postcolonialism. London: Routledge. 


\section{Postcolonial theory as a hermeneutical tool for Biblical reading}

Malina, B J 1983. The social sciences and biblical Interpretation, in Gottwald, K N (ed), The Bible and liberation: Political and social hermeneutics, 11-23. Maryknoll, NY: Orbis Books.

Malina, B J \& Rohrbaugh, R L 1992. Social-science commentary on the Synoptic Gospels. Minneapolis, MN: Fortress.

Mazrui, A A 1980. Beyond dependency in the black world: five strategies for decolonisation, in Yansané, Y A (ed), Decolonization and dependency. Problems of development of African societies, 84-97. London: Greenwood.

Mbiti, J 1992. Is Jesus Christ in African religion?, in Pobee1992:21-31.

Mesters, C 1995. A Brazilian example, "Listening to what the Spirit is saying to the churches": Popular interpretation of the Bible in Brazil, in Sugirtharajah 1995:407-420.

Moore, S D 1994. Poststructuralism and the New Testament: Derrida and Foucault at the foot of the cross. Minneapolis, MN: Fortress.

Moore, S D 2001. Postcolonialism, in Adam 2001:182-188.

Mosala, I J 1996. Race, class, and gender as hermeneutical factors in the African Independent Churches' appropriation of the Bible. Semeia 73, 43-58.

Nkrumah, K 1968. Handbook of revolutionary warfare. London: Panaf.

Okure, T 1995. Reading from this place: Some problems and prospects, in Segovia \& Tolbert 1995:52-66.

Pobee, S J (ed) 1992. Exploring Afro-Christianity. Frankfurt: Peter Lang.

Pui-lan, K 1996. Response to the Semeia volume on postcolonial criticism. Semeia 75, 211-217.

Punt, J 2001. The New Testament, theology and imperialism: Some postcolonial remarks on beyond New Testament theology. Neotestamentica 35(1-2), 129145

Punt, J 2003. Postcolonial biblical criticism in South Africa: Some mind and road mapping. Scriptura, 37(1), 58-85.

Riley, M W 1963. Sociological research, I: A case approach. New York: Harcourt.

Robbins, K V 1995. Social-scientific criticism and literary studies: Prospects for cooperation in biblical interpretation, in Esler 1995:274-289.

Rohrbaugh, L R (ed)1996. The social sciences and the New Testament interpretation. Peabody, MA: Hendrickson.

Rohrbaugh, L R 1996. Introduction, in Rohrbaugh 1996:1-14.

Schroer, S \& Bietenhard, S (eds) 2003. Feminist interpretation of the Bible and the hermeneutics of liberation. Sheffield: Sheffield.

Segovia, F F 1995a. Cultural studies and contemporary biblical criticism: Ideological criticism as mode of discourse, in Segovia, F F \& Tolbert A M (eds) 1995. Reading from this place: Social location and biblical interpretation in global perspective, Vol 2, 1-17. Minneapolis, MN: Fortress.

Segovia, F F 1995b. Toward intercultural criticism: A reading strategy from the Diaspora, in Segovia \& Tolbert 1995:303-330.

Segovia, F F 1999. Notes toward refining the postcolonial optic. JSNT 75, 103-114.

Segovia, F F ed) 2000. Interpreting beyond borders. Sheffield: Sheffield.

Senghor, S L 1964. On African socialism, tr by Mercer Cook. London: Pall Mall. 
Sugirtharajah, S R 1995a. Introduction: The margin as a site of creative revisioning, in Sugirtharajah, S R (ed), Voice from the margin. Interpreting the Bible in the Third World, 1-8. London: SPCK.

Sugirtharajah, S R 1995b. Afterword: Cultures, texts and margins: A hermeneutical odyssey, in Sugirtharajah 1995:457-475.

Sugirtharajah, S R 1996. Textual cleansing: A move from the colonial to the postcolonial version. Semeia 76, 7-19.

Sugirtharajah, S R 1999. A brief memorandum on postcolonialism and biblical studies. JSNT 73, 3-5.

Sugirtharajah, S R 2001. The Bible and the Third World: Precolonial, colonial and postcolonial encounters. Cambridge: Cambridge University Press.

Tamez, E 1996. The hermeneutical leap of today. Semeia 75, 203-205.

Tolbert, A M 1995. Afterwords: Christianity, imperialism, and decentering of privilege, in Segovia \& Tolbert 1995:347-347.

Ukpong, J 2001. New Testament hermeneutics in Africa: Challenges and possibilities. Neotestamentica 35 (1-2), 147-167.

Van Aarde, A G 2002. Methods and models in the quest for the historical Jesus: Historical criticism and/or social scientific criticism. HTS 58(2), 419-439.

Van Aarde, A G 2004. Some thoughts on post-colonial hermeneutics and New Testament scholarship: Public lecture as visiting professor at the Evangelical Theological Seminary in Cairo (Egypt) on November 16, 2004. Reworked version of paper presented at the NRF Regional Conference "Shifting boundaries of knowledge - the role of social sciences, law and humanities", 28 May 2004, Tshwane University of Technology, Pretoria. Published in Afrikaans in 2004 in HTS 60(3), 1105-1125.

Van Staden, P 1991. Compassion - the essence of life: A social-scientific study of the religious symbolic universe reflected in the ideology/theology of Luke. (HTS Suppl 4.)

Van Zanthen Gallagher, S 1996. Mapping the hybrid world: Three postcolonial motifs. Semeia 75, 229-240.

Vledder, E-J 1997. Conflict in the miracle stories: A socio-exegetical study of Matthew 8 and 9. Sheffield: Sheffield Academic Press.

Wainwright, M E 1998. Shall we look for another?: A feminist reading of the Matthean Jesus. New York: Orbis.

Wire, A C 1991. Gender in a scribal community, in Balch, L D (ed). Social history of the Matthean community: Cross-disciplinary approaches, 87-121. Minneapolis, MN: Fortress.

Yansané, Y A 1980. Decolonization, dependency, and development in Africa: The theory revisited, in Yansané, Y A (ed), Decolonization and dependency. Problems of development of African societies, 3-51. London: Greenwood. 